\title{
Critical Reflection about Knowledge Management in a Participatory Planning, Monitoring \& Evaluation Course
}

\author{
Alberto Un Jan' 1 , Vilma Contreras ${ }^{2}$ \\ ${ }^{1}$ Facultad de Ingeniería, Universidad Norbert Wiener, Lima, Perú \\ ${ }^{2}$ Cántaros Peruanos, Lima, Perú \\ Email: a84@wienergroup.com,cantarosperuanos@gmail.com
}

Received 4 September 2015; accepted 19 March 2016; published 24 March 2016

Copyright (C) 2016 by authors and Scientific Research Publishing Inc.

This work is licensed under the Creative Commons Attribution-NonCommercial International License (CC BY-NC).

http://creativecommons.org/licenses/by-nc/4.0/

(c) (i) (9) Dpen Access

\section{Abstract}

This article reports an initiative to manage knowledge in a Participatory Planning, Monitoring \& Evaluation (PPM\&E) course given at Wageningen University Research Centre (WURC), from the experience of the authors when they attended the course. The United Nations Population Fund, UNFPA [1], shows the importance of participatory monitoring and evaluation (M\&E), and highlights the difference and principles which distinguish conventional M\&E from participatory M\&E. For Göergens and Zall [2], vital questions are: "How will we know success when we achieve it?" and "So what?". M\&E helps answer these questions. The Royal Tropical Institute [3] works on strengthening primary stakeholder involvement when applied to village participation in rural development. The way WURC [4] looks at PPM\&E is as "Managing and Learning for Impact". WURC focuses on $M \& E$, and relates the application of it to manage for impact. The article shows how knowledge is managed to identify the meaning, contents and application of PPM\&E, based on two versions of the PPM\&E course given in 2012 and 2013 at WURC. Experiences from applying the knowledge acquired in the 2012 course, after it was ended, are presented by participants who worked on PPM\&E projects. The participants confirm a useful application of the PPM\&E tools. Participants at the 2012 course report applications of the course to their jobs, and mention the different tools they apply. Next, experiences during the 2013 course are presented. Emphasis is given on the use of PPM\&E tools during the course; assistants are reporting initial applications. The results shown explain the benefits of attending the course, for its later application. A survey has been run by the authors to both groups to measure the usefulness of the tools explained during the course. With this annual course, WURC promotes the combination of information with experience, context, interpretation and reflection; the information about experience in PPM\&E has a high value for participants and is prepared to be applied in decision making and in back home action plans prepared by the participants. In this sense, WURC contributes to knowledge management. The results shown explain the benefits of attending the course, for its later application. Also, the course ex- 
plains the benefit of monitoring and evaluation, and highlights the difference and principles which distinguish "conventional monitoring \& evaluation" from "participatory monitoring \& evaluation". Knowledge in PPM\&E has been managed in multinational, multidisciplinary teams at WURC, and the experience is repeated every year in a three-week course. Participants come from all over the world, provided that they work in PPM\&E projects. Knowledge has been discovered from the experiences, examples and applications described by the participants.

\section{Keywords}

Participatory Planning, Monitoring and Evaluation (PPM\&E), Managing for Impact (M4I)

\section{Introduction}

The United Nations Population Fund, UNFPA [1], introduces a Program Manager's Planning, Monitoring and Evaluation Toolkit, Number 4: Stakeholder Participation in Monitoring and Evaluation. With this tool, UNFPA shows the importance of participatory monitoring and evaluation (M\&E), and highlights the difference and principles which distinguish conventional M\&E from participatory M\&E. In another definition by Göergens and Zall [2], when development programs are expected to deliver results, vital questions are: "How will we know success when we achieve it?" and "So what?". M\&E helps answer these questions. The Royal Tropical Institute [3], under the slogan: "We think. We share. We act." introduces a kit dossier in its web page, and works on strengthening primary stakeholder involvement, when applied to village participation in rural development.

The way WURC [4] looks at PPM\&E is as:

“... 'Managing and Learning for Impact.' Over the last years, there is a growing demand/interest for:

More focus on the outcomes and impact of development investments.

... Therefore a new approach to M\&E is needed that is an integral part of project management, in which stakeholders participate and learning takes place, to create real impact.”

WURC focuses on M\&E, and relates the application of it to managing for impact (M4I). The contribution of WURC is given as courses and consultancy.

The previous definitions are based on the work that the authors and institutions do mostly in the third world countries, in villages, working with sanitary projects; water, agriculture, food, health projects; minority groups, for example, orphans, people with diseases, and people who lost their lands.

WURC gives a three-week PPM\&E course once a year. As a preparation to the course, the participants are asked to write a report on their experience on PPM\&E, and to send it to WURC before attending the course. Participants in the course come from all over the world, and have experience in their home countries applying PPM\&E. WURC has the following objectives:

- WURC promotes sharing of knowledge in the field of PPM\&E by gathering the experience of the participants once a year.

- WURC promotes the combination of information with experience, context, interpretation and reflection.

- The information about experience in PPM\&E is prepared to be applied in back home action plans prepared by the participants.

In this sense, WURC contributes to knowledge management, according to the definitions given by Davenport [5] and Uriarte [6]. This article reports the outcomes from the Participatory Planning, Monitoring \& Evaluation (PPM\&E) course given at WURC. The authors of this article attended the course at WURC: B.S. Contreras attended the course in 2012 and Dr. Un Jan attended the course in 2013. The title of this article comes from the fact that during the course, each day began with a critical reflection about what had been done in the previous day; this reflection could be a summary of activities, a summary and explanation of main concepts, and the opinion about the usefulness of the concepts.

Section 2 of this article describes the infrastructure of a PPM\&E course and the contents of it at WURC. Section 3 reports the challenges to overcome from the 2012 and 2013 PPM\&E course given at WURC. Section 4 describes how the initiative was received. Section 5 shows efficiency with the result of a survey run to test the usefulness of the tools learnt during the course. Finally, the conclusions show the contribution of WURC to 
knowledge management in PPM\&E from the examples and applications described by the participants. Their cases are related to minorities in need.

\section{Infrastructure}

WURC focuses on monitoring \& evaluation (M\&E), and relates the application of it to managing for impact (M4I).

\subsection{Resources for the Course}

Two main resources are identified: Persons (Human capital) and experiences. WURC invites groups of experts in PPM\&E, who gather every year to share experiences. As a result, intellectual capital is built through interaction of persons in the course, with a common function of describing their experiences. Esteban \& Navarro [7] describe this kind of interaction.

\subsection{Type of Knowledge}

The courses begin working with tacit knowledge: skills and experiences of the persons are stored in their minds. The courses are a tool to transform tacit knowledge into explicit knowledge. Finally, the explicit knowledge is the start point for future projects (Uribe-Tirado, Melgar-Estrada, \& Bornacelly-Castro [8]; Dalkir [9]). Knowledge shared in the courses is both external: the environment to apply PPM\&E; and internal: procedures, norms, operations and organization.

The PPM\&E course is helpful to develop tacit knowledge (Dalkir [9]):

- The course develops in the participants the ability to adapt, to deal with new and exceptional situations.

- The course develops in the participants expertise about knowhow, know-why and care-why.

- The course develops in the participants the ability to collaborate, to share a vision, and to transmit a culture.

- The course uses coaching and mentoring to transfer experimental knowledge on a one-to-one, face to face basis.

Also, the PPM\&E course helps develop explicit knowledge:

- The course develops in the participants the ability to disseminate, to reproduce, to access, and to reapply throughout the organization.

- The course develops in the participants the ability to organize, to systematize; to translate a vision into a mission statement, into operational guidelines

- The course itself transfers knowledge via products, services, and documented processes.

Dalkir [9] mentions stories as a vehicle for both capturing and coding tacit knowledge. An organizational story is defined as a detailed narrative of past management actions, employee interactions, or other key events that have occurred and that have been communicated informally. The course at WURC, applying the definition of stories, captured stories using rich pictures.

\section{Challenges}

Challenges were overcome with different resources, in terms of communications and organization. The main challenge was related to the course itself.

Challenges in terms of communications: The course begins every year with an invitation to participants from countries in South America, Africa, Asia and Oceania. The first challenge is to avoid any cultural misunderstanding among the participants, but also break barriers that begin with the diversity of native languages. All the participants speak English as a foreign language; the lectures are given in English and the services for the three week course (hotel, meals, leisure) are given in English. Multicultural and multilingual situations can be a barrier to knowledge management, since understanding comes from interpersonal relations if a good communication is granted.

Challenges in terms of running the course: The real challenge was to "manage the knowledge" among the participants. To manage knowledge, the course was run in three stages, one stage per week:

- Week one was for the lectures and team work,

- Week two was for the conferences given by external guests, and

- Week three was conclusions. 
In this way the challenge of managing knowledge was accomplished.

This is the real challenge in terms of bringing together projects, sharing projects, selecting projects to share.

The projects presented by the participants during the three week courses were local projects performed in their home countries, most of them financed by local NGO's. The challenge during the course was to select the most suitable project to share with other participants; once selected the project had to be explained and worked by participants from different countries. This challenge was for the facilitators who had to conduct the project selection, but also for participants to understand and further work to improve the project.

\section{Outcomes from Two Versions of the Course}

\subsection{Outcomes from the 2012 PPM\&E Course at WURC}

One month after the 2012 PPM\&E course ended at WURC, some of the participants reported applications of the tools they had learnt. For example, the Wheel evaluation tool was applied by one of the 2012 participants working at "FHI 360 THE SCIENCE OF IMPROVING LIVES". He described: “This is a participatory evaluation after events; it is applied with stakeholders”. Another 2012 participant from Actionaid in Nigeria presented his action plan applying Managing for impact (M4I) during a learning meeting with staff, to provoke discussions within the organization. In his presentation, the concept outcome was used after the concept output, as a consequence of it. As the input went into a block of capability to deliver development objectives, this block gave an output; the output entered a next block and was transformed into outcome. The outcome was used to feedback the capability block. The title of this chapter uses the word outcome to show a higher level than an output.

\subsection{Examples Worked in the 2013 PPM\&E Course at WURC}

The PPM\&E 2013 course at WURC had 91 participants, coming from Africa, Middle East, Oceania, and South America. The different tools were applied during the three week course, and also as initial experiences of the participants immediately after the course were finished. A model to represent M\&E presented by the facilitator during the course is shown in Figure 1:

During the course, a great discussion arose about the difference between output, outcome and result. The 2012 course also found and explained this difference. When the two authors compared their experiences from consecutive years, they discovered common concepts, that, when identified, is part of the knowledge managed by WURC.

Cases from the 2013 participants: The participants in the 2013 course were asked to present their cases, which would be used as case studies for applying the M\&E tools. Six cases were presented, five of them were chosen. The contents of the cases correspond mostly to NGO's, orphans, HIV, agriculture and water projects. For example, case 5 is about the orphans and vulnerable children (OVC) in Nigeria. The case was worked consolidating key characteristics: Current situation, Concerns versus assumptions and Strategies. From the situation presented using the tools given for M\&E, strategies were proposed that can be used as a start point for action planning.

Field Case: The participants in the 2013 course were invited to visit COS Consulting ONG, which receives funding from the Dutch Ministry of Foreign Affairs. Later, participants gave analysis and recommendations to COS.

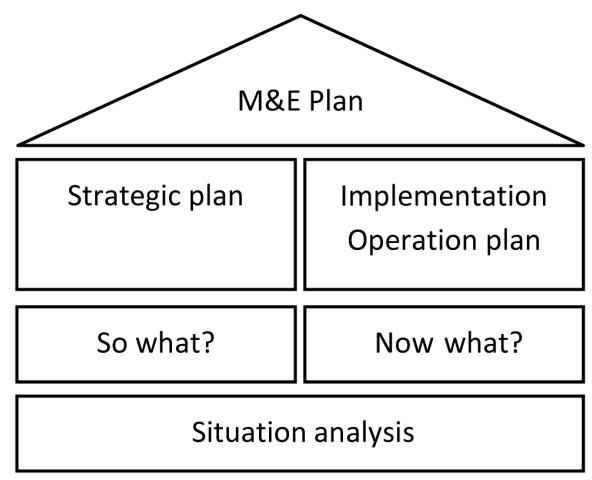

Figure 1. M\&E plan. 
Short cases after the course: Participant 1: I arrived home safely on Sunday evening and my immediate desired future (wife and children) were on hand to receive me in Northern Namibia. While sitting at Amsterdam (airport) waiting for the flight I could paint the Rich Picture in my mind. Arriving at the International Airport in Namibia, I found out astonishingly that my luggage did not arrive. The flight to the northern town where I live was delayed for almost 3 hours due to technical hitches and I couldn't help thinking of the Theory of Change (TOC) all along. Just this afternoon the airline called me that my luggage has made it down to the local airport and am about to go and pick it up. Sometimes the TOC does not work out as envisaged.

Participant 2: Your TOC failed because you made wrong assumptions and probably your strategies too!

In another experience, one participant reported that "I just finished a facilitation session for all Focal Persons of the Ministries, Departments and Agencies in Ekiti State, Nigeria. The project template will monitor and track performance status of individual projects and contracts awarded by the State Tenders Board through corresponding Ministries".

Participatory approach: The previous examples were worked in groups, with a high participatory approach. Apart from the course, other activities were also participatory. Since the first day, introduction of each participant was in pairs, each participant introducing one of his colleagues. Workgroups were formed around tables; however, different groups were formed from different tables according to the exercises and concepts developed. Activities worked in groups were: Critical reflections, housekeeping and animation, journalism. Leadership was developed by assigning two leaders per week, a male and a female leader. Social activities, such as outside dinners, and a short visit to Amsterdam were also scheduled. In the 2012 course, the groups adopted names of fruits, for example the Apple group, while in the 2013 course the groups adopted names of animals.

\section{Efficiency}

To confirm the use of acquired knowledge, an e-mail survey about the usefulness of the PPM\&E course was passed to the 2012 and 2013 participants. E-mails were sent to 54 participants. The scale used to collect opinions is shown in Table 1:

The concepts evaluated and the mean values obtained are shown in Table 2.

The values obtained in Table 2 are above $50 \%$ of the scale used, and show the usefulness of the concepts, and in general, the usefulness of the knowledge acquired. WURC has published a complete list of tools at: http://www.mspguide.org/tools-and-methods.

\section{Plans}

\subsection{Back Home Action Plan}

A product delivered from the course by each participant is a back home action plan (BHAP). This plan tells what the participant will do in terms of applying the tools from the course as soon as he/she comes back to his/ her home country. Author Dr. Un Jan applied his BHAP to Universidad Norbert Wiener, in Lima, Peru. This BHAP began using a rich picture with the description of the current situation at Universidad Wiener. The rich picture shows that the market share for Universidad Wiener is lower than for other universities, and therefore the monetary incomes are lower than expected. A strong concern at Universidad Wiener is quality, which corresponds to two paths: growing with quality for 2012-2013, and quality in education. When identifying the stakeholders, a chart of power versus interest is used. Finally, the plans for 2013 to 2015 are depicted in a timeline.

\subsection{Future Plans}

From this research, the application of BHAP is expected. In terms of knowledge management, BHAP should be a way of sharing knowledge acquired during the course, and also an opportunity to measure the transfer of knowledge.

\section{Table 1. Scale of usefulness for PPM\&E concepts.}

\begin{tabular}{|c|c|c|c|c|c|c|}
\hline $\begin{array}{l}\text { Please rate the } \\
\text { usefulness of the } \\
\text { following concepts }\end{array}$ & $\begin{array}{c}\text { 0: The concept } \\
\text { was not } \\
\text { a applied }\end{array}$ & $\begin{array}{l}\text { 1: The concept } \\
\text { was not useful }\end{array}$ & $\begin{array}{l}\text { 2: The concept } \\
\text { was mildly } \\
\text { useful }\end{array}$ & $\begin{array}{l}\text { 3: The } \\
\text { concept was } \\
\text { useful }\end{array}$ & $\begin{array}{c}\text { 4: The concept } \\
\text { was } \\
\text { very useful }\end{array}$ & $\begin{array}{l}\text { 5: The concept } \\
\text { was } \\
\text { extremely useful }\end{array}$ \\
\hline
\end{tabular}


Table 2. Average usefulness for PPM\&E concepts.

\begin{tabular}{|c|c|}
\hline Concept & Average usefulness \\
\hline 1. Goals, Reality, Options, Wrap up (GROW) & 3.53 \\
\hline \multicolumn{2}{|l|}{ M4I-Seven Building Blocks: } \\
\hline 2. Providing strategic guidance towards impact & 3.68 \\
\hline 3. Ensuring effective operations & 3.79 \\
\hline 4. Establishing sound M\&E & 4.11 \\
\hline 5. Connecting to future context dynamics & 3.68 \\
\hline 6. Facilitating people engagement & 4.05 \\
\hline 7. Creating a learning environment & 4.15 \\
\hline 8. Supporting capacities and conditions & 3.73 \\
\hline 9. Pretty's ladder of participation & 3.53 \\
\hline \multicolumn{2}{|l|}{ Theories of change in project design } \\
\hline 10. The logical framework. Zigzag activities: outputs, purpose, goals & 3.78 \\
\hline 11. Objectively verifiable indicators: OVI & 4.00 \\
\hline 12. Means of verification: MOV & 4.05 \\
\hline 13. Source of verification: SOV & 4.00 \\
\hline \multicolumn{2}{|l|}{ Operations management } \\
\hline 14. Action plan by quarters & 3.82 \\
\hline 15. Staff & 3.59 \\
\hline 16. Procurement & 3.35 \\
\hline 17. Financial & 3.5 \\
\hline \multicolumn{2}{|l|}{ Implementation } \\
\hline 18. Identify indicators and other information needs & 3.83 \\
\hline 19. Identify base line information & 4.00 \\
\hline 20. Collect and process data & 3.89 \\
\hline
\end{tabular}

\section{Conclusion}

Knowledge Management has been applied to PPM\&E at WURC. Methods used include a permanent calendar offering a course once a year. The course is offered to participants with experience in PPM\&E who will share their experiences with case studies from their own countries. PPM\&E has been applied by participants after the course, as shown by 2012 and 2013 participants with the reports. Positive results about applications are also noticed by the survey answered. Experiences given by the participants, during the course and after the course, show the effectiveness of knowledge management at WURC.

\section{Acknowledgements}

The authors would like to acknowledge the work done by our facilitator, Seerp Wigboldus, and by the course leader and organizer, Cecile Kusters and her team, in 2012 and 2013. The participation of author Dr. Un Jan in the course has been financed by the Netherlands Fellowship Program and encouraged by Universidad Norbert Wiener and the rector Dr. Luis Bullon.

\section{References}

[1] UNFPA (2004) Tool Number 4: Stakeholder Participation in Monitoring and Evaluation. Programme Manager’s Planning Monitoring \& Evaluation Toolkit. UNFPA Division for Oversight Services. 
http://betterevaluation.org/sites/default/files/stakeholder.pdf

[2] Göergens, M. and Zall, J. (2010) Making Monitoring and Evaluation Systems Work: A Capacity Development Tool Kit. World Bank Series.

[3] Royal Tropical Institute (2013) http://www.kit.nl/

[4] WURC (2013) http://www.wageningenur.nl/en.htm

[5] Davenport, T. (1998) Successful Knowledge Management Projects. Sloan Management Review. Winter, 43-57.

[6] Uriarte, F. (2008) Introduction to Knowledge Management. Asean Foundation, Jakarta.

[7] Esteban, M. and Navarro, D. (2003) Gestión del Conocimiento y servicios de inteligencia: la dimensión estratégica de la información. El profesional de la información, 12, 269-281.

[8] Uribe-Tirado, A., Melgar-Estrada, L. and Bornacelly-Castro, J. (2007) Utilización de Moodle en la gestión de información, documental y del conocimiento en grupos de investigación. El profesional de la información, 16, 468474.

[9] Dalkir, K. (2005) Knowledge Management in Theory and Practice. McGill University, Montreal. 